\title{
Adubação verde e nitrogenada na cultura do trigo em plantio direto
}

\author{
Ricardo Viola; Giovani Benin (*); Luís César Cassol; Cilas Pinnow; Mariana Faber Flores; Elesandro Bornhofen \\ Universidade Tecnológica Federal do Paraná (UTFPR). Programa de Pós-Graduação em Agronomia, Rodovia PR 469, Km 01, 85501 -970 \\ Pato Branco (PR), Brasil. \\ ${ }^{*}$ ) Autor correspondente: benin@utfpr.edu.br
}

Recebido: 11/maio/2012; Aceito: 25/fev./2013

\section{Resumo}

Pouco se sabe sobre os benefícios do cultivo de adubos verdes sobre o desempenho da cultura do trigo, cultivada em sucessão e, até que ponto, pode substituir ou reduzir a adubação nitrogenada mineral. Objetivou-se com o presente trabalho avaliar a produção e decomposição de matéria seca bem como o acúmulo e liberação de nutrientes de plantas de cobertura de solo (nabo forrageiro, ervilhaca comum, ervilha forrageira, tremoço e feijoeiro) e quantificar seus efeitos sobre o desempenho da cultura do trigo, cultivada em sucessão, sob diferentes doses de adubação nitrogenada (sem adição de nitrogênio, 40, 80 e 120 kg ha ${ }^{-1}$ ). 0 experimento foi desenvolvido no município de Pato Branco (PR), em duas safras agrícolas, em sistema de plantio direto. O nabo forrageiro e o tremoço acumularam as maiores quantidades de cálcio e potássio. A ervilha forrageira e o nabo forrageiro destacam-se pela produção de matéria seca, acúmulo de nitrogênio, fósforo, potássio, bem como pela decomposição e liberação de nitrogênio para a cultura do trigo em estádios fenológicos de maior demanda deste nutriente. A relação C/N (superior a 40) dos restos culturais do milho e feijoeiro não possibilitou equilíbrio entre os processos de mineralização e imobilização. Os adubos verdes promoveram acréscimos significativos na produtividade de grãos em comparação ao pousio. Houve resposta do trigo à aplicação de nitrogênio mineral, e esta foi dependente da planta de cobertura antecessora.

Palavras-chave: Triticum aestivum L., nabo forrageiro, tremoço, ervilha forrageira, ciclagem de nutrientes.

\section{Green manure and nitrogen fertilization in the spring wheat under no-tillage}

\begin{abstract}
There are few studies about the benefits of green manure on wheat performance grown in succession as source of nitrogen. Therefore, this study aimed to evaluate the dry matter production and nutrient accumulation in wheat and the dry matter decomposition and nutrient release of cover crops forage turnip, common vetch, forage pea, lupine and bean and quantify their effects over wheat crop performance sown in succession under different nitrogen rates (without $\mathrm{N}$ addition, 40,80 and $120 \mathrm{~kg} \mathrm{ha}^{-1}$ ). The experiment was carried out in Pato Branco (PR, Brazil) during two crop seasons in no-tillage system. Oilseed radish and lupine accumulated the largest amounts of calcium and potassium. Forage pea and oilseed radish stand out with the highest dry matter production, nitrogen, phosphorus, potassium accumulation. Forage pea and oilseed radish also decomposed faster and released nitrogen to wheat at growth stages with high demand for this nutrient. The $\mathrm{C} / \mathrm{N}$ ratio (above at 40) as evidenced by the maize straw and bean residue did not allow the adequate balance between mineralization and immobilization process. Cover crops promoted significant increases in wheat grain yield compared to fallow. There was a wheat response to mineral nitrogen rates, and this was dependent on the green manures cultivated before wheat.
\end{abstract}

Key words: Triticum aestivum L., forage turnip, lupine, forage pea, nutrient cycling.

\section{INTRODUÇÃO}

O trigo é o principal cultivo de inverno na Região Sul do Brasil. Para que a triticultura se estabeleça como atividade economicamente rentável, é necessário utilizar manejos que maximizem a produtividade, com sustentabilidade. Dentre as práticas de manejo disponíveis para a cultura do trigo, a adubação verde destaca-se por melhorar os atributos químicos, físicos e biológicos do solo, a baixo custo (Nunes et al., 2011).
Um esquema de sucessão de culturas, comumente adotado na Região Sudoeste do Estado do Paraná, é a semeadura do feijoeiro no período entre a colheita do milho (final de fevereiro) e a semeadura do trigo (meados de junho). Entretanto, a maior parte das áreas permanece em pousio. Em função da elevada relação $\mathrm{C} / \mathrm{N}$ da palhada do milho, esta mobiliza maior quantidade de nitrogênio para a sua decomposição (WENDLING et al., 2007). Este é um problema quando se cultiva em sucessão uma cultura também exigente em nitrogênio, que é o caso da cultura do trigo. 
Neste contexto, fica evidente a necessidade de ampliar os estudos com o cultivo de plantas de cobertura no período outonal, entre o cultivo de veráo e a semeadura do trigo. Para anteceder a cultura do trigo, paralelamente ao acúmulo de nutrientes, é imprescindível que os adubos verdes produzam matéria seca (MS) com relação $\mathrm{C} / \mathrm{N}$ que proporcione equilíbrio entre a mineralização e a imobilização dos nutrientes e o nitrogênio seja mineralizado, principalmente, nos estádios de maior demanda da cultura do trigo.

As leguminosas, pela sua capacidade de fixação de nitrogênio, tornam-se alternativas interessantes para o cultivo de outono, antecedendo o trigo. Diversos trabalhos demonstram o potencial da ervilhaca comum (Arta et al., 2001; Giacomini et al., 2003b; Almeida e CÂmara, 2007), ervilha forrageira e de tremoço (ArtA et al., 2001) e nabo forrageiro (Almeida e CÂMARA, 2007; Lima et al., 2007), em substituir ou complementar a adubação nitrogenada, com contribuiçôes de nitrogênio que variam entre 76 e $240 \mathrm{~kg} \mathrm{ha}^{-1}$; na maioria desses trabalhos, os adubos verdes foram cultivados antes da cultura do milho. Cultivadas em sucessão ao milho, a ervilha forrageira e o nabo forrageiro podem contribuir com até $80 \mathrm{~kg} \mathrm{ha}^{-1} \mathrm{de} \mathrm{N}$ para o trigo (KochHann et al., 2003; Voss et al., 2004). Entretanto, conforme observou Alvarenga et al. (1995), o desempenho de cada espécie deve ser avaliado para cada particularidade de solo, clima e situaçáo econômica do agricultor.

Poucos estudos avaliaram o efeito do cultivo de adubos verdes, cultivados em sucessão à cultura do milho, sobre o desempenho da cultura do trigo. Em comparação ao cultivo em pousio, a ervilha forrageira (Voss et al., 2004) e a crotalária (NunEs et al., 2011) podem resultar em aumentos de, respectivamente, $8 \%, 12 \%$ e $27 \%$ na produtividade de grãos do trigo. Em trigo irrigado, Braz et al. (2006) observaram resultados semelhantes.

Assim, os objetivos deste trabalho foram: a) Avaliar a produção e decomposição de matéria seca e o acúmulo e a liberação de nutrientes de plantas de cobertura de solo (nabo forrageiro, ervilhaca comum, ervilha forrageira, tremoço; b) Quantificar o efeito das plantas de cobertura sobre o desempenho da cultura do trigo, em diferentes doses de adubação nitrogenada.

\section{MATERIAL E MÉTODOS}

O experimento foi instalado em uma propriedade particular no município de Pato Branco (PR), em solo

Tabela 1. Atributos químicos do solo, na profundidade de $0-10 \mathrm{~cm}$, antes da implantaçáo do experimento em dois anos. Pato Branco (PR), 2012

\begin{tabular}{|c|c|c|c|c|c|c|c|c|c|}
\hline \multirow{2}{*}{ Ano } & $\mathrm{pH}$ & M.O. & $\mathrm{H}+\mathrm{Al}$ & $\mathrm{Ca}$ & Mg & K & $\mathbf{P}$ & m & V \\
\hline & $\mathrm{CaCl}_{2}$ & $\left(\mathrm{~g} \mathrm{dm}^{-3}\right)$ & \multicolumn{4}{|c|}{$\left(\mathrm{cmol}_{(\mathrm{c})} \mathrm{dm}^{-3}\right)$} & $\left(\mathrm{mg} \mathrm{dm}^{-3}\right)$ & $(\%)$ & (\%) \\
\hline 2009 & 4,9 & 43 & 7,20 & 5,62 & 2,77 & 0,65 & 7,83 & 0,00 & 55,67 \\
\hline 2010 & 4,8 & 49 & 6,69 & 5,08 & 2,64 & 0,48 & 10,77 & 0,00 & 55,07 \\
\hline
\end{tabular}

M.O.: matéria orgânica; $\mathrm{m}(\%)$ : saturaçăo por alumínio; V (\%): saturaçăo por bases.
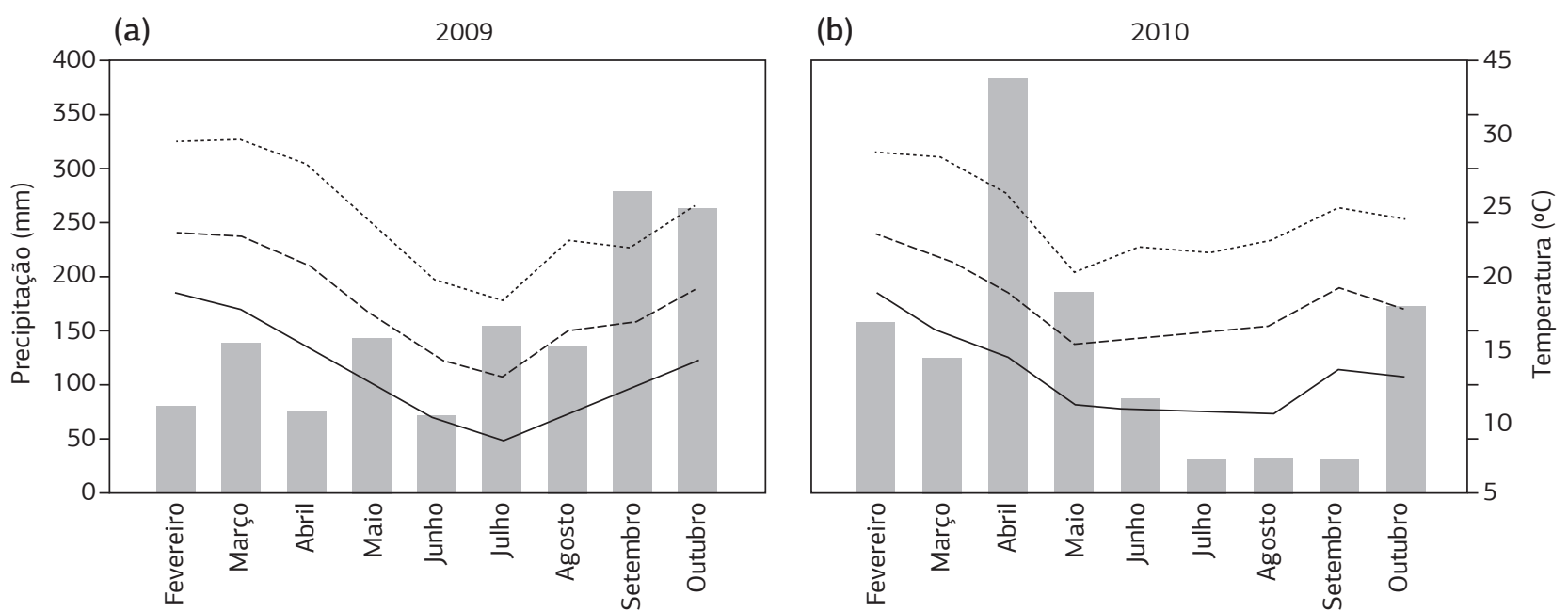

Precipitação _ _ Temperatura mínima …... Temperatura máxima ---- Temperatura média

Figura 1. Precipitação pluvial e temperaturas mínima, média e máxima referentes ao período experimental de 2009 (a) e 2010 (b). Pato Branco (PR), 2010. 
classificado como Latossolo Vermelho distroférrico, de textura argilosa, com relevo ondulado. A área experimental, localizada a $26^{\circ} 10^{\prime} 38^{\prime \prime S}$; 52041'24"O, e 800 metros de altitude, vem sendo desenvolvida no sistema plantio direto desde 1987. Anteriormente à instalaçáo dos experimentos, foram coletadas amostras de solo (10 subamostras por amostra composta) na profundidade de $0-10 \mathrm{~cm}$, para realizaçấo da análise química (Tabela 1). Os dados meteorológicos durante o período experimental podem ser observados na figura 1.

As espécies de cobertura nabo forrageiro (Raphanus sativus L.), ervilhaca comum (Vicia sativa L.), tremoço (Lupinus albus L.), ervilha forrageira (Pisum sativum subsp. Arvense, cultivar BRS Forrageira) e feijoeiro (Phaseolus vulgaris L., cultivar IAPAR 81), além de uma parcela que permaneceu em pousio, foram implantadas em 25/2/2009 e 4/3/2010, no sistema plantio direto, sobre resteva de milho. As espécies de cobertura foram implantadas com uma semeadora de parcelas experimentais marca Semina/Embrapa, utilizando-se 30, 80, 15 e $80 \mathrm{~kg} \mathrm{ha}^{-1}$ de sementes, para a ervilha forrageira, ervilhaca comum, o nabo forrageiro e tremoço respectivamente. As parcelas foram compostas de nove linhas com quatro metros de comprimento, espaçadas em 0,2 metros, totalizando uma área útil de $7,2 \mathrm{~m}^{2}$. Para a cultura do feijáo, foram utilizadas sete sementes por metro linear, com adubação de base de $200 \mathrm{~kg} \mathrm{ha}^{-1}$ do fertilizante (N-P-K), fórmula 05-20-20.

A avaliação da produção de matéria seca (MS) das espécies de cobertura ocorreu em 13/6/2009 e 12/6/2010 (108 e 100 dias após a semeadura respectivamente). Aleatoriamente, cortaram-se três amostras de $0,25 \mathrm{~m}^{2}$ por parcela das plantas de cobertura e recolheu-se $0,25 \mathrm{~m}^{2} \mathrm{da}$ palhada remanescente do milho, na área que permaneceu em pousio. Para a cultura do feijáo, a coleta do material vegetal ocorreu logo após a colheita. As amostras foram secas em estufa com circulação forçada de ar a $65^{\circ} \mathrm{C}$ até massa constante, para obtenção da MS. Em ambas as safras agrícolas, no momento da avaliação, a ervilhaca comum estava em fase de desenvolvimento vegetativo, o tremoço no início do florescimento, a ervilha forrageira em pleno florescimento e o nabo forrageiro no fim do florescimento. Posteriormente à coleta, as espécies de cobertura foram manejadas através de dessecação, com a aplicação de $5 \mathrm{~L} \mathrm{ha}^{-1}$ do herbicida glifosato.

Em 19/6/2009 e 18/6/2010, a cultivar de trigo BRS Pardela foi semeada em sucessão às culturas de cobertura e ao pousio. Utilizou-se o delineamento de blocos ao acaso, em três repetiçóes, com os tratamentos dispostos em esquema fatorial. Na cultura do trigo, para os tratamentos com adubação nitrogenada mineral, foram aplicados $250 \mathrm{~kg} \mathrm{ha}^{-1}$ do fertilizante N-P-K (08-20-15). Nas parcelas sem N, utilizou-se a formulação 00-20-15 (N-P-K). O restante do nitrogênio, na forma de uréia, foi aplicado em cobertura no início do afilhamento para a dose de $40 \mathrm{~kg} \mathrm{ha}^{-1}$ de $\mathrm{N}$ e parcelado em duas aplicaçóes no início e fim do afilhamento (escala 4 e 5 de FeekesLarge respectivamente), para as doses de 80 e $120 \mathrm{~kg} \mathrm{ha}^{-1}$ de $\mathrm{N}$, objetivando melhor aproveitamento do fertilizante. O rendimento de grãos $(R G)$ foi determinado pela colheita e trilha da área útil da parcela, corrigido para a umidade de $13 \%$ (base úmida) e transformado para $\mathrm{kg} \mathrm{ha}^{-1}$.

As amostras utilizadas para a determinação de matéria seca dos adubos verdes, feijoeiro e palhada do milho foram submetidas à análise para determinaçáo dos teores de $\mathrm{N}$, $\mathrm{P}, \mathrm{K}$ e Ca, segundo método proposto por TEDEsCO at al. (1995). Também foi determinada a relação C/N. A avaliação da taxa de decomposição do resíduo vegetal, bem como a taxa de liberação de nutrientes, realizada na safra agrícola de 2009, foi realizada através do método do uso de sacos de decomposição ou litter bags, os quais foram confeccionados em nylon com dimensões de $20 \times 20 \mathrm{~cm}$ e malha de 2,0 mm. Os litter-bags receberam $10 \mathrm{~g}$ de MS triturada dos adubos verdes, feijoeiro e palhada do milho e foram alocados nas entrelinhas da cultura do trigo, logo após sua semeadura (13/6/2009), sendo coletados após $14,28,42,56,70$ e 100 dias.

O material proveniente dos litter bags foi seco em estufa a $65^{\circ} \mathrm{C}$ até massa constante. A porcentagem do material remanescente foi calculada com base na quantidade total $(10 \mathrm{~g})$ alocada no início das avaliaçóes menos a quantidade remanescente ao longo dos períodos de avaliação. Logo após, o material foi triturado em moinho tipo Willey (<40 mesh) e submetido à análise química para estimar a taxa de liberação de N, P e K ao longo do tempo. Após a digestão sulfúrica, o $\mathrm{N}$ total foi determinado em destilador de arraste de vapor semimicro Kjeldhal. Na mesma alíquota obtida na digestáo, foram determinados os teores totais de $\mathrm{P}$ e K, respectivamente, por espectrofotometria e fotometria de chama (Tedesco et al., 1995).

Foram testadas a homogeneidade e a normalidade dos erros do modelo matemático, via testes de Bartlett (STELL et al., 1997) e Lilliefors (CAMPos, 1983) respectivamente. Os dados referentes à produção de matéria seca, relação $\mathrm{C} / \mathrm{N}$ e ao acúmulo e à liberação de nutrientes das espécies de cobertura e o rendimento de gráos da cultura do trigo foram submetidos à análise de variância conjunta, com efeitos fixos (espécies intercalares e doses de adubação nitrogenada) e aleatórios (anos de avaliaçáo). O efeito das doses de adubação nitrogenada foi analisado por regressão polinomial, testados até o grau de polinômio cúbico. A escolha do modelo equacional para as regressôes considerou a significância dos parâmetros da equação de regressão ajustada testados pelo teste F e teste $t$ de Student $(\mathrm{p}<0,05)$. As médias foram comparadas pelo teste de Tukey $(\mathrm{p}<0,05)$.

As taxas de decomposição da MS dos resíduos vegetais das plantas e a liberação de nutrientes foram estimadas ajustando-se modelos de regressão não linear aos valores observados, conforme proposto por Wieder e LANG (1982). A partir dos valores da constante de decomposição da MS e 
liberação de nutrientes de cada compartimento, calculou-se o tempo da meia vida $\left(\mathrm{t}^{1 / 2}\right)$, ou seja, o tempo necessário para que $50 \%$ da MS daquele compartimento fosse decomposta ou 50\% dos nutrientes fossem liberados. Para este cálculo utilizou-se a fórmula deduzida por PAUL e Clark (1996): $\mathrm{t}^{1 / 2}=0,693 / \mathrm{k}_{(\mathrm{a}, \mathrm{b})}$ As análises foram realizadas por meio dos aplicativos Genes (Cruz, 2006) e Statgraphics, sendo os gráficos gerados com o aplicativo SigmaPlot versão 11.0.

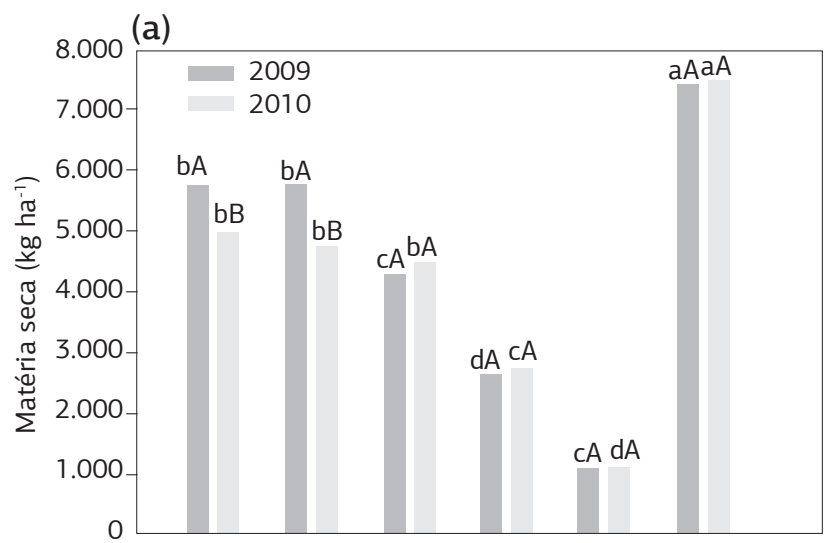

(c)

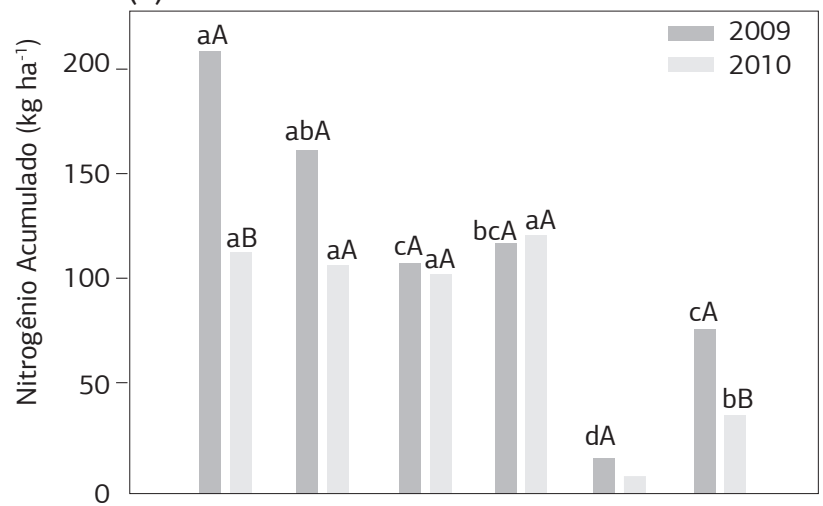

(e)

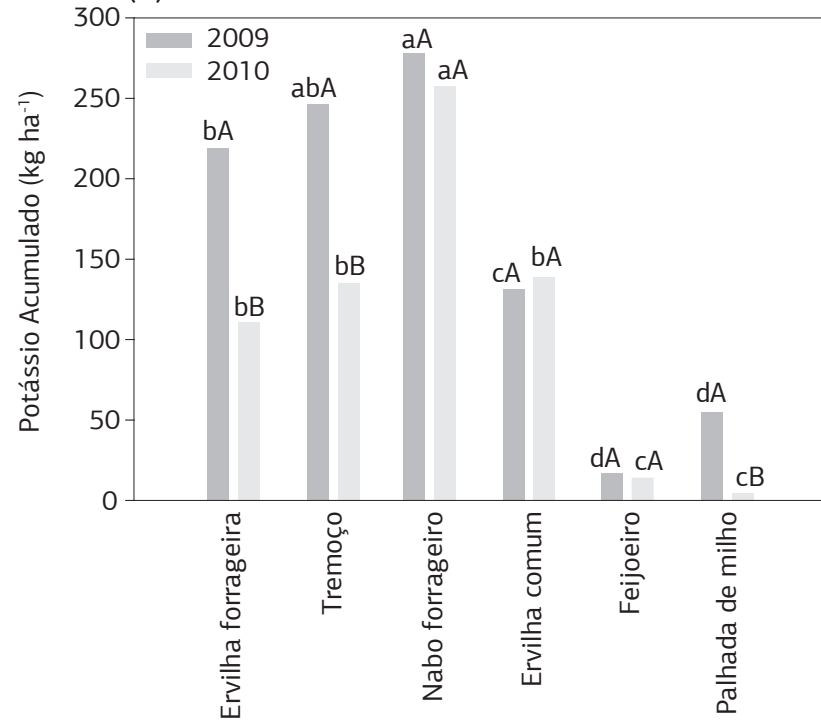

\section{RESULTADOS E DISCUSSÃO}

A produção de MS das espécies outonais não diferiu estatisticamente entre anos, exceto para o tremoço $\left(5752 \mathrm{~kg} \mathrm{ha}^{-1}\right)$ e a ervilha forrageira $\left(5774 \mathrm{~kg} \mathrm{ha}^{-1}\right) \mathrm{em}$ 2009, que tiveram melhor desempenho em comparação a 2010. Em 2010, o comportamento foi semelhante, no entanto, a produção de matéria seca da ervilha forrageira

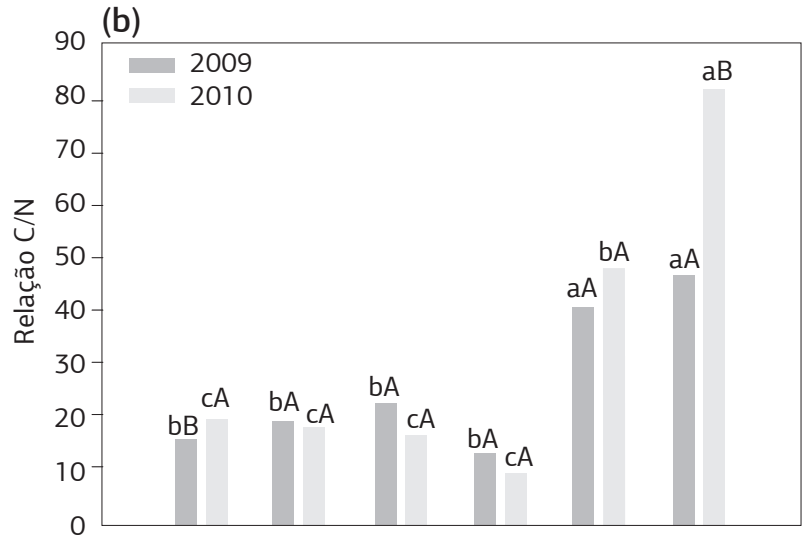

(d)
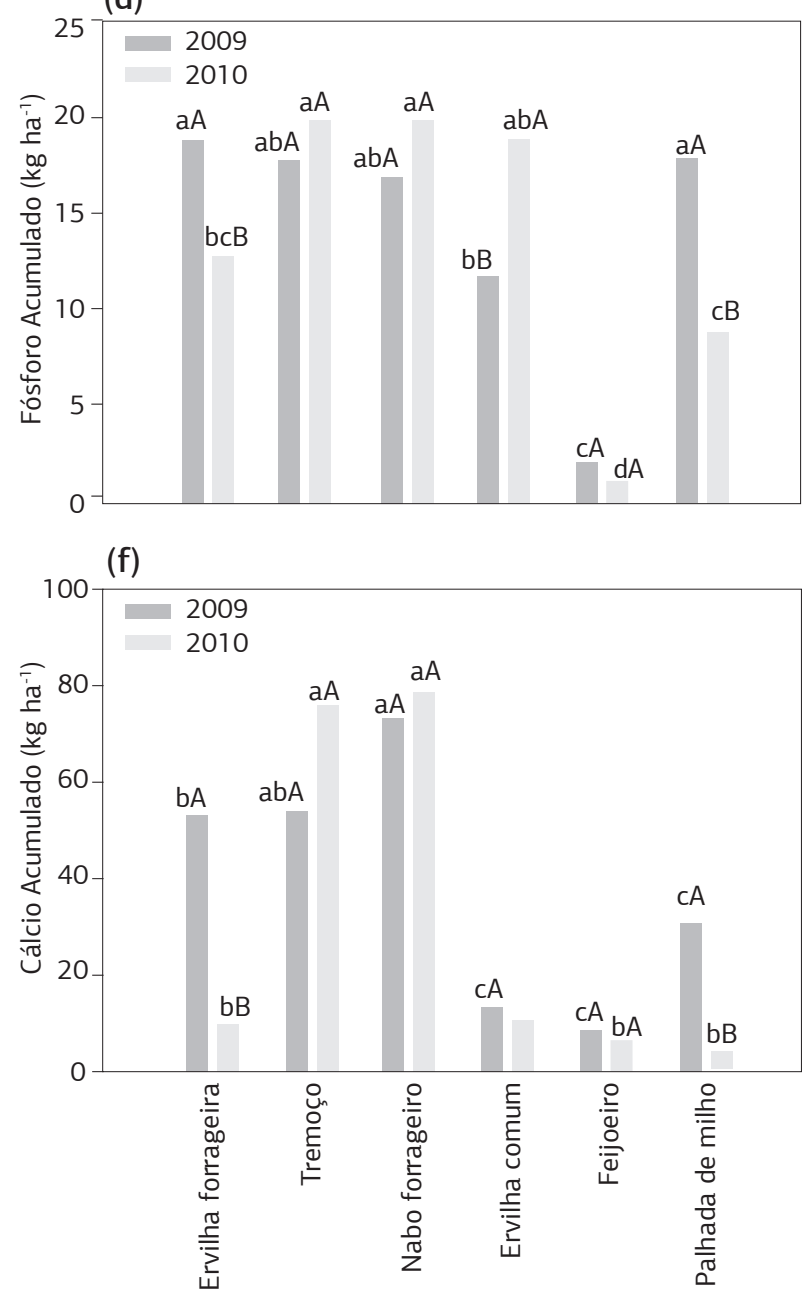

Figura 2. Produção de matéria seca (a), relação $\mathrm{C} / \mathrm{N}$ (b) e acúmulo de nitrogênio (c), fósforo (d), potássio (e) e cálcio (f) na parte aérea, de diferentes espécies outonais e palhada de milho em dois anos. Médias seguidas com letras minúsculas no ano e maiúsculas entre anos, não diferem significativamente pelo teste de Tukey a 5\%. Pato Branco (PR), 2010. 
$\left(5001 \mathrm{~kg} \mathrm{ha}^{-1}\right)$ não diferiu do tremoço $\left(4767 \mathrm{~kg} \mathrm{ha}^{-1}\right) \mathrm{e}$ do nabo forrageiro (4487 kg ha ${ }^{-1}$ ) (Figura 2a). A baixa produçáo de matéria seca da ervilhaca comum pode ser atribuída ao seu crescimento inicial lento e à época de manejo das coberturas (Nunes et al., 2011). A produção de matéria seca das demais espécies avaliadas, na maioria das vezes, foi superior às observadas em outros estudos (Aita et al. 2001; Heinrichs et al., 2001; Agostinetto et al., 2000; Voss et al., 2004; Almeida e CÂmara, 2007; Lima et al., 2007). Esse resultado pode ser atribuído à adaptabilidade das espécies às condiçóes climáticas da Regiẫo Sudoeste do Paraná (Figura 1) e a elevada fertilidade do solo (Tabela 1) no local de instalação do experimento.

A relação $\mathrm{C} / \mathrm{N}$ de nabo forrageiro, ervilha forrageira, ervilhaca comum e tremoço (Figura $2 b$ ), indica que a mineralização tende a ser superior à imobilização, com maior disponibilizaçáo de nitrogênio durante o processo de decomposição dos restos vegetais, o que é benéfico ao trigo, cultivado em sucessão. Outros estudos apontam estas espécies com relação $\mathrm{C} / \mathrm{N}$ adequada para o cultivo antecedendo gramíneas (HeinRichs et al., 2001; Aita et al., 2001;Lıma et al., 2007). Ao contrário, a elevada relação $\mathrm{C} / \mathrm{N}$ da palhada do milho (64) e do feijoeiro (44) pode acarretar em maior imobilizaçáo de $\mathrm{N}$.

Em 2009, os maiores acúmulos de nitrogênio foram observados para a ervilha forrageira $\left(209 \mathrm{~kg} \mathrm{ha}^{-1}\right)$ e o tremoço $\left(162 \mathrm{~kg} \mathrm{ha}^{-1}\right)$. Em 2010, a ervilha forrageira $\left(113 \mathrm{~kg} \mathrm{ha}^{-1}\right)$, o tremoço $\left(107 \mathrm{~kg} \mathrm{ha}^{-1}\right)$, o nabo forrageiro $\left(103 \mathrm{~kg} \mathrm{ha}^{-1}\right)$ e a ervilhaca comum $\left(121 \mathrm{~kg} \mathrm{ha}^{-1}\right)$ tiveram os maiores acúmulos de nitrogênio, diferindo significativamente da palhada de milho e do feijoeiro (Figura 2c). O bom desempenho da ervilha forrageira e do tremoço deve-se à elevada produçáo de MS (Figura 2a) e concentração do nutriente (Figura 2c). Aita et al. (2001) observaram acúmulos de 69 e $113 \mathrm{~kg} \mathrm{ha}^{-1}$ de N, respectivamente, para a ervilha forrageira e o tremoço, confirmando a importância destas espécies em esquemas de rotação/sucessão com espécies que demandam altas doses de adubaçáo nitrogenada. Os resultados obtidos para a ervilhaca comum corroboram com Giacomini et al. (2003b). Quanto ao nabo forrageiro, o acúmulo observado foi superior ao relatado por Giacomini et al. (2003b) e Almeida e CÂMara (2007) e inferior ao observado por Lima et al. (2007).

A ervilha forrageira, o nabo forrageiro, tremoço e a ervilhaca comum acumularam entre 13 e $20 \mathrm{~kg} \mathrm{ha}^{-1}$ de $\mathrm{P}$ (Figura 2d). Giacomini et al. (2003b) observaram acúmulos de 12 e $14 \mathrm{~kg} \mathrm{ha}^{-1}$ de $\mathrm{P}$ para a ervilhaca comum e o nabo forrageiro respectivamente. $\mathrm{O}$ nabo forrageiro proporcionou o melhor desempenho quanto ao acúmulo de K (277 e $257 \mathrm{~kg} \mathrm{ha}^{-1}$ de K, respectivamente, em 2009 e 2010), e em 2009, não diferiu do tremoço (Figura 2e). Embora a ervilha forrageira tenha superado o nabo forrageiro em produção de matéria seca, este acumulou maiores quantidades de K. Ao comparar o acúmulo de nutrientes na parte aérea do nabo forrageiro com diferentes espécies de adubos verdes, Lima et al. (2007) também destacaram seu potencial em reciclar $\mathrm{P}, \mathrm{K}$, Ca e Mg. $\mathrm{O}$ feijoeiro e a palhada remanescente de milho tiveram os menores acúmulos de $\mathrm{K}$, o que pode ser atribuído à baixa produção de MS observada para o feijoeiro (Figura 2a) e pelo tempo entre a colheita do milho e a coleta da palhada para análise (110 dias e 115 dias para 2009 e 2010 respectivamente). Em ambos os anos, o nabo forrageiro e o tremoço foram às espécies que tiveram os maiores acúmulos de cálcio (Figura 2f).

Em todos os tratamentos, com exceçáo dos restos culturais do milho e feijoeiro, que tiveram taxa de decomposição mais lenta, a dinâmica da decomposição foi semelhante, com uma fase inicial rápida, seguida de outra mais lenta (Figura 3). Segundo Wieder e LANG (1982), no início do processo são decompostos açúcares e proteínas, restando para o fim o material recalcitrante (celulose e lignina). Aos 15 dias após a alocação em campo dos litter bags, as taxas de decomposição foram de 39, 32, $28,24,14$ e $5 \%$, respectivamente, para o nabo forrageiro, ervilhaca comum, ervilha forrageira, tremoço, feijoeiro e milho. Aos 28 dias, 44 e $45 \%$ da matéria seca inicial do nabo forrageiro e da ervilhaca comum respectivamente, ainda permaneciam na superfície do solo; estes resultados diferem de Aita e Giacomini (2003) em que, para o mesmo período, relatam permanência de 75 e $57 \%$ da matéria seca inicial para nabo forrageiro e da ervilhaca comum respectivamente. A partir do quinquagésimo sexto dia da alocação dos litter bags, ocorreu maior estabilização da taxa de decomposição, com a porcentagem de matéria

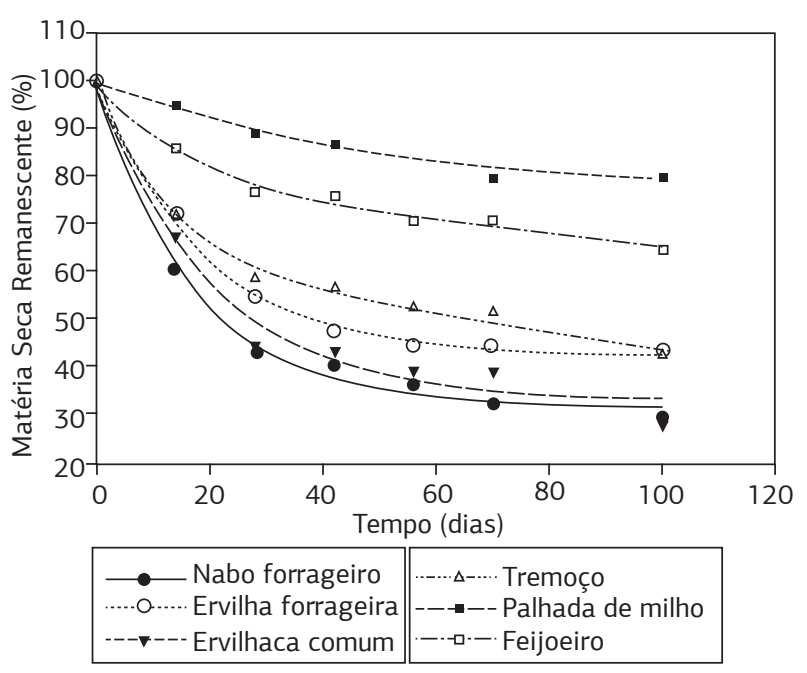

Figura 3. Comportamento da matéria seca remanescente de nabo forrageiro, ervilha forrageira, ervilhaca comum, tremoço, palhada de milho e do feijoeiro durante cem dias de avaliação. As estimativas dos parâmetros do modelo exponencial simples e duplo, ajustados aos valores medidos da matéria seca, estão incluídas na tabela 2 . Pato Branco (PR), 2010. 
seca remanescente variando de 37 a $86 \%$, com o maior residual observado para a palhada do milho e o menor para o nabo forrageiro (Figura 3). Aos cem dias, observou-se na ervilhaca comum a maior decomposiçáo $(71 \%)$, seguida do nabo forrageiro (70\%), tremoço $(57 \%)$ e ervilha forrageira (56\%). A maior velocidade de decomposição da ervilhaca comum pode ser atribuída ao maior ciclo desta espécie, sendo manejada antes do florescimento e, consequentemente, com menor relação $\mathrm{C} / \mathrm{N}$ (Figuras $2 \mathrm{~b}$ e 3 ). Neste período, os tratamentos com maiores teores de matéria seca remanescente foram o feijoeiro $(65 \%)$ e a palhada de milho (80\%).

As constantes de decomposição (Tabela 2) de nabo forrageiro, ervilha forrageira e ervilhaca comum se ajustaram ao modelo exponencial simples (um compartimento). No modelo assintótico, apenas o compartimento mais facilmente decomponível, relativo à matéria seca, é transformado, diminuindo exponencialmente com o tempo a uma taxa constante. A matéria seca do segundo compartimento é considerada mais recalcitrante e, por isso, não ocorre transformação no período de tempo considerado (Wieder e Lang, 1982; Aita e Giacomini, 2003). Para o tremoço, a palhada de milho e o feijoeiro, o modelo que melhor se ajustou às taxas de decomposição foi o exponencial duplo. As menores velocidades de decomposição observadas para a palhada de milho e do feijoeiro podem ser atribuídas à elevada concentração de lignina, conferindo a esses materiais maior resistência à ação e penetração de microrganismos decompositores.

A maior constante de decomposição para o compartimento $\mathrm{k}_{\mathrm{a}}$ foi observada para o tremoço, cujo compartimento mais facilmente decomponível levou um período de 6,9 dias para decompor $50 \%$ da matéria seca; por outro lado, o compartimento mais recalcitrante do tremoço proporcionou uma constante de decomposição $\left(\mathrm{k}_{\mathrm{b}}\right)$ de 0,00396 , resultando em uma meia vida de 175 dias, o que é desejável para a maior permanência dos resíduos culturais sobre a superfície do solo. O nabo forrageiro propiciou o maior percentual de matéria seca no compartimento mais facilmente decomponível $(67,59 \%)$, com uma constante de decomposição de 0,05870, resultando em uma meia vida de 11,8 dias; comportamento semelhante foi observado para a ervilhaca comum e ervilha forrageira, indicando

Tabela 2. Parâmetros do modelo exponencial simples e duplo, ajustados aos valores medidos da matéria seca, nitrogênio, fósforo e potássio remanescentes de nabo forrageiro, ervilha forrageira, ervilhaca comum, tremoço, palhada de milho e feijoeiro, constantes de decomposição $\left(\mathrm{k}_{\mathrm{a}}\right.$ e $\mathrm{k}_{\mathrm{b}}$ ), tempo de meia vida $\left(\mathrm{t}^{1 / 2}\right)$ de cada compartimento e valores de $\mathrm{R}^{2}$. Pato Branco (PR), 2010

\begin{tabular}{|c|c|c|c|c|c|c|}
\hline \multirow{3}{*}{ Tratamentos } & \multirow{3}{*}{$\begin{array}{l}\text { A } \\
(\%)\end{array}$} & \multirow{3}{*}{$\begin{array}{c}k_{a} \\
\left(\operatorname{dia}^{-1}\right)\end{array}$} & \multirow{3}{*}{$\begin{array}{c}\mathbf{k}_{\mathrm{b}} \\
\left(\mathrm{dia}^{-1}\right)\end{array}$} & \multicolumn{2}{|c|}{$t^{1 / 2}$} & \multirow{3}{*}{$\mathbf{R}^{2}$} \\
\hline & & & & A & $(100-A)$ & \\
\hline & & & & (dia) & (dia) & \\
\hline & \multicolumn{6}{|c|}{ Matéria seca remanescente } \\
\hline Nabo forrageiro & 67,59 & 0,05870 & - & 11,8 & - & 0,90 \\
\hline Ervilha forrageira & 57,59 & 0,05083 & - & 13,6 & - & 0,93 \\
\hline Ervilhaca comum & 66,11 & 0,05057 & - & 13,7 & - & 0,95 \\
\hline Tremoço & 33,79 & 0,09948 & 0,00396 & 6,9 & 175,1 & 0,94 \\
\hline Palhada de milho & 23,31 & 0,01915 & 0,00009 & 36,1 & $6.996,5$ & 0,73 \\
\hline \multirow[t]{2}{*}{ Feijoeiro } & 19,33 & 0,07829 & 0,00203 & 8,8 & 341,5 & 0,85 \\
\hline & \multicolumn{6}{|c|}{ Nitrogênio remanescente } \\
\hline Nabo forrageiro & 61,11 & 0,01707 & - & 40,6 & - & 0,63 \\
\hline Ervilha forrageira & 36,27 & 0,02752 & - & 25,1 & - & 0,32 \\
\hline Ervilhaca comum & 56,50 & 0,15135 & - & 4,5 & - & 0,86 \\
\hline Tremoço & 34,82 & 0,18088 & 0,00734 & 3,8 & 94,6 & 0,88 \\
\hline Palhada de milho & 79,46 & 0,00973 & 0,00767 & 71,2 & 90,3 & 0,43 \\
\hline \multirow[t]{2}{*}{ Feijoeiro } & 68,56 & 0,04581 & 0,00314 & 15,1 & 220,9 & 0,43 \\
\hline & \multicolumn{6}{|c|}{ Fósforo remanescente } \\
\hline Nabo forrageiro & 39,33 & 0,02132 & - & 32,5 & - & 0,67 \\
\hline Ervilha forrageira & 40,60 & 0,02033 & - & 34 & - & 0,44 \\
\hline Ervilhaca comum & 33,12 & 0,01232 & - & 56,2 & - & 0,47 \\
\hline Tremoço & 75,48 & 0,01025 & - & 67,6 & - & 0,75 \\
\hline Palhada de milho & 32,74 & 0,00677 & 0,00147 & 102,4 & 469,8 & 0,75 \\
\hline \multirow[t]{2}{*}{ Feijoeiro } & 40,41 & 0,21609 & 0,00283 & 3,2 & 245,2 & 0,80 \\
\hline & \multicolumn{6}{|c|}{ Potássio remanescente } \\
\hline Nabo forrageiro & 94,22 & 0,13282 & - & 5,2 & - & 0,99 \\
\hline Ervilha forrageira & 91,37 & 0,19294 & - & 3,6 & - & 0,99 \\
\hline Ervilhaca comum & 93,21 & 0,11419 & - & 6,1 & - & 0,99 \\
\hline Tremoço & 95,10 & 0,19493 & - & 3,5 & - & 0,99 \\
\hline Palhada de milho & 87,97 & 0,02748 & - & 25,2 & - & 0,66 \\
\hline Feijoeiro & 82,85 & 0,15613 & - & 4,4 & - & 0,95 \\
\hline
\end{tabular}


o potencial destas espécies em disponibilizar nutrientes a partir dos estádios iniciais de desenvolvimento da cultura implantada em sucessão. Devido à elevada relação $\mathrm{C} / \mathrm{N}$ (Figura 2b), verificou-se na palhada do milho a menor constante de decomposição $\left(\mathrm{k}_{\mathrm{a}}=0,01915\right)$ e o maior tempo de meia vida (Tabela 2 ).

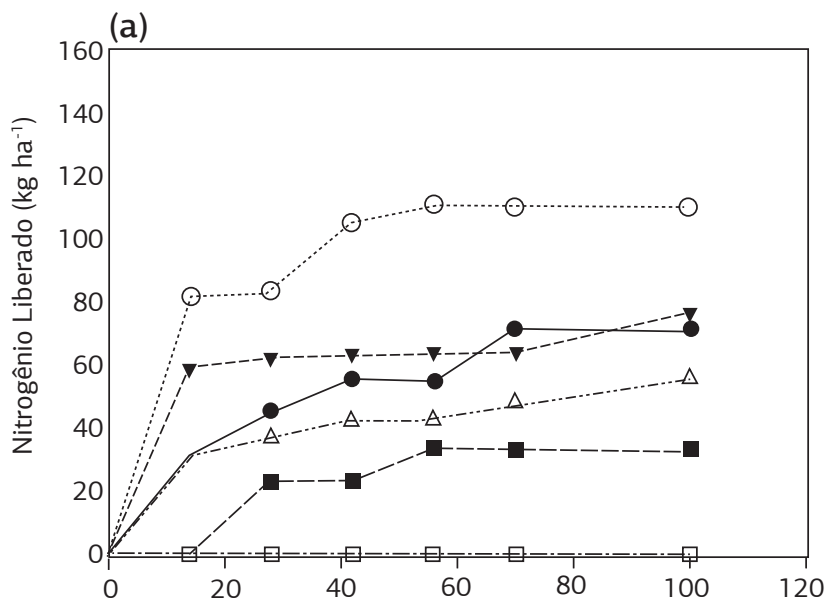

(c)
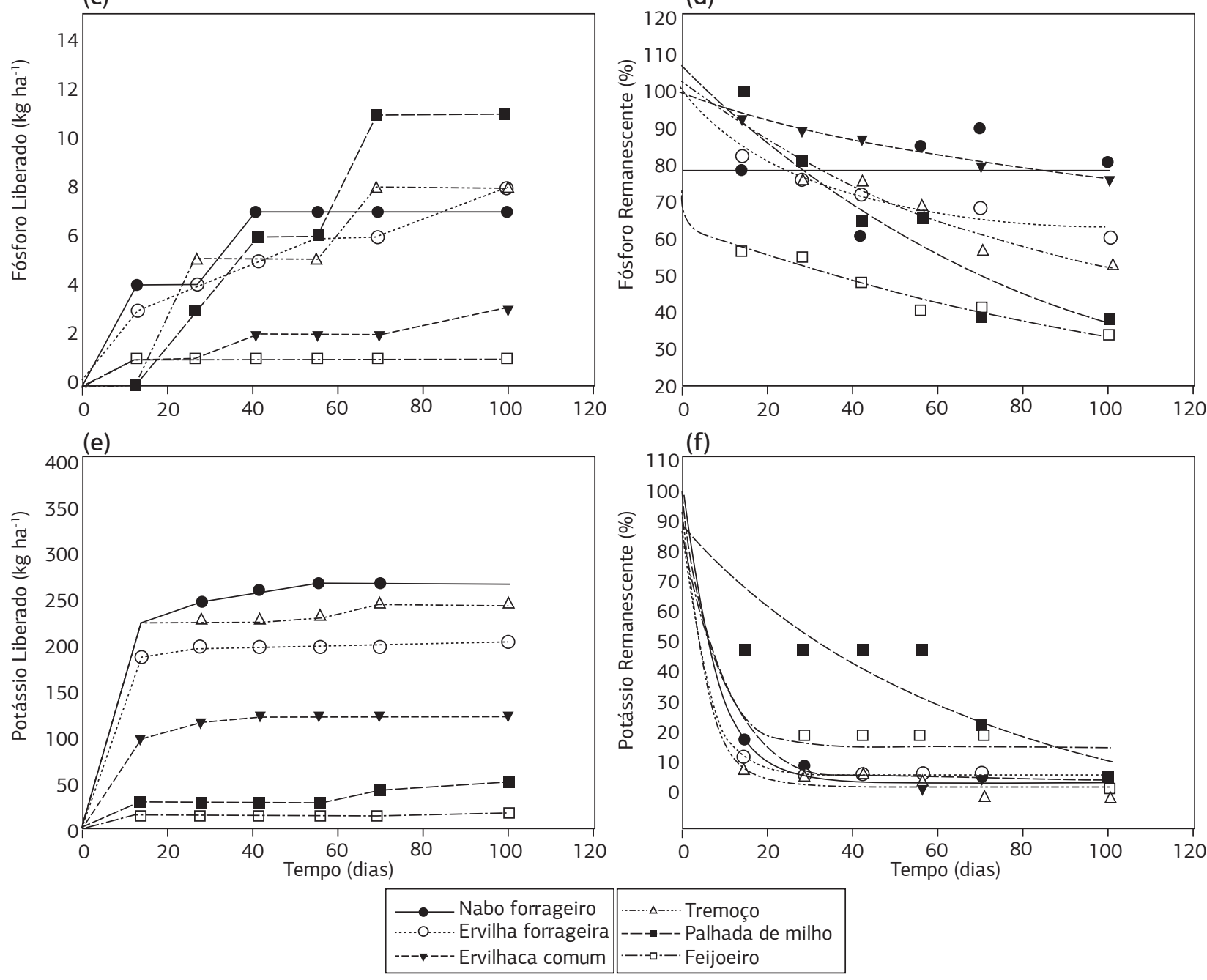

As maiores liberações de $\mathrm{N}$, nos primeiros 14 dias, foram observadas para a ervilhaca comum (51\%), ervilha forrageira (39\%) e o tremoço (38\%) (Figura 4a). Aos 28 dias após a deposição dos litter bags, a ervilha forrageira, o tremoço e a ervilhaca comum contribuíram com, respectivamente, 84 e $63 \mathrm{~kg} \mathrm{ha}^{-1}$ de nitrogênio, enquanto a

(b)

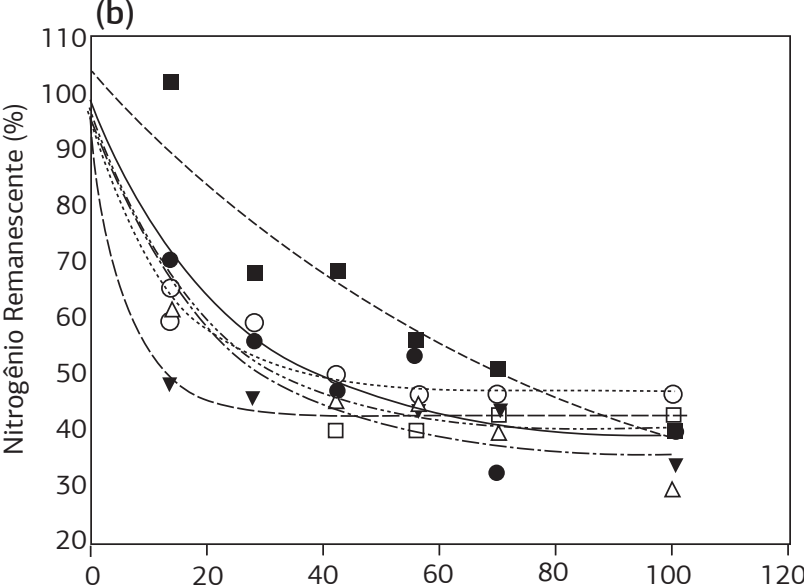

(d)

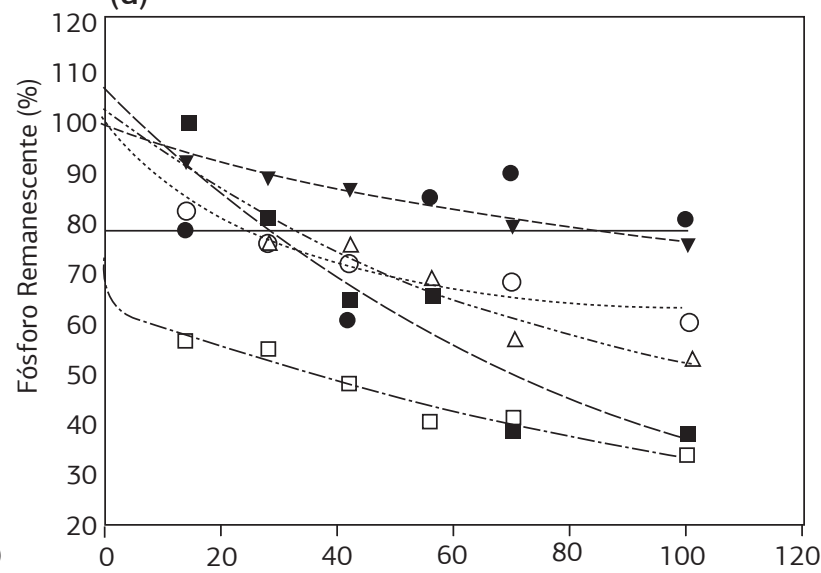

Figura 4. Nitrogênio, fósforo e potássio, liberado e remanescente, em função das espécies outonais e da palhada de milho durante cem dias de avaliação. As estimativas dos parâmetros do modelo exponencial simples e duplo, ajustados aos valores de nitrogênio, fósforo e potássio, liberado e remanescente, estáo incluídas na tabela 2. Pato Branco (PR), 2010. 
palhada de milho contribuiu com apenas $24 \mathrm{~kg} \mathrm{ha}^{-1}$; no fim do período de avaliação, tais espécies contribuíram com a totalidade de 111, 56, 77 e $34 \mathrm{~kg} \mathrm{ha}^{-1}$ de nitrogênio respectivamente. $\mathrm{O}$ nabo forrageiro se destacou com uma contribuição de $46 \mathrm{~kg} \mathrm{ha}^{-1}$ de $\mathrm{N}$ aos 28 dias e $71 \mathrm{~kg} \mathrm{ha}^{-1}$ de no fim do período (Figura 4a). Aos 42 dias após a deposição dos litter bags, 41, 46, 48 e 50\% do nitrogênio remanescente ainda estava presente na palhada do feijoeiro, tremoço, da ervilhaca comum e ervilha forrageira respectivamente (Figura $4 \mathrm{~b}$ ).

A quantidade de nitrogênio presente no compartimento mais recalcitrante foi superior na palhada de milho, com meia vida de 90,3 dias. Dentre as espécies testadas, a maior constante de decomposição $\mathrm{k}_{\mathrm{a}}$ foi observada para o tremoço $(0,18088)$, com meia vida de 94,6 dias do compartimento mais recalcitrante. $\mathrm{O}$ nabo forrageiro levou 40,6 dias para liberar 50\% do nitrogênio presente na MS, o que é desejável para a dinâmica de fornecimento desse nutriente à cultura cultivada em sucessão. A ervilhaca comum proporcionou $56,5 \%$ do nitrogênio presente no compartimento mais facilmente decomponível, levando apenas 4,5 dias para liberar $50 \%$ do nitrogênio total contido nos resíduos vegetais.

A liberação de nitrogênio do nabo forrageiro, da ervilha forrageira e da ervilhaca comum se ajustou ao modelo assintótico simples e o tremoço, a palhada de milho e o feijoeiro se ajustaram ao modelo duplo (Tabela 2). Para um eficiente fornecimento de nutrientes, é essencial que ocorra sincronia entre o nutriente liberado pelos restos culturais das espécies de cobertura e a demanda da cultura implantada em sucessão (STUTE e Posner, 1995); caso contrário, podem ocorrer perdas de nutrientes por lixiviação (LARA-CABEZAS et al., 2000). Neste contexto, os resíduos do nabo forrageiro e da ervilha forrageira tiveram uma liberação gradativa do $\mathrm{N}$, que podem suprir de forma mais adequada os estádios de maior demanda deste nutriente pela cultura do trigo. A liberação do fósforo da matéria seca remanescente do nabo forrageiro, da ervilha forrageira, ervilhaca comum e do tremoço se ajustou ao modelo simples e a palhada de milho e feijoeiro, ao modelo duplo (Tabela 2). A palhada de milho proporcionou a menor quantidade de fósforo na porçâo mais prontamente decomponível $(32,7 \%)$, levando aproximadamente 102 dias para liberar $50 \%$ do nutriente. No tremoço, a maior parte do fósforo esteve no compartimento mais prontamente decomponível, com uma meia vida de 67 dias. Ainda na tabela 2, observa-se que o tremoço proporcionou a maior quantidade de potássio na porção mais prontamente decomponível $(95,1 \%)$, com uma meia vida de 3,5 dias. O nabo forrageiro, a ervilha forrageira, ervilhaca comum e o tremoço tiveram mais de $90 \%$ do potássio na fração mais prontamente decomponível e com meia vida inferior a sete dias.

Dentre as culturas outonais, a ervilha forrageira foi responsável pelo maior teor de nitrogênio liberado, proporcionando $111 \mathrm{~kg} \mathrm{ha}^{-1}$ deste nutriente para a cultura do trigo até aos cem dias após a dessecação, sendo seguida pela ervilhaca comum e pelo nabo forrageiro, com liberação de 77 e $71 \mathrm{~kg} \mathrm{ha}^{-1}$ de N, respectivamente (Figura 4a). A maior quantidade de fósforo liberada foi observada na palhada de milho, chegando no fim do período com liberação total de $11 \mathrm{~kg} \mathrm{ha}^{-1}$. A ervilha forrageira e o tremoço acumularam $8 \mathrm{~kg} \mathrm{ha}^{-1}$ de $\mathrm{P}$ ao fim dos cem dias de avaliação (Figura 4c). O nabo forrageiro $\left(266 \mathrm{~kg} \mathrm{ha}^{-1}\right) \mathrm{e}$ o tremoço $\left(243 \mathrm{~kg} \mathrm{ha}^{-1}\right)$ se destacaram com as maiores quantidade de potássio liberada ao fim dos 100 dias. Aos 14 dias, apenas cerca de $20,14,26$ e $10 \%$ do potássio o nabo forrageiro, ervilha forrageira, ervilha comum e tremoço, respectivamente, ainda permaneciam nos resíduos culturais (Figura 4f), corroborando com os resultados de Giacomini et al. (2003a). A rápida liberação do potássio decorre do fato desse elemento náo estar associado a nenhum componente estrutural do tecido vegetal e com alta mobilidade na planta, tanto entre tecidos como entre células (Meurer e IndA, 2004).

Em 2009, ocorreu resposta quadrática do rendimento de grãos às doses de adubação nitrogenada em sucessão ao tremoço e feijoeiro, com as maiores produtividades (2807 e $2822 \mathrm{~kg} \mathrm{ha}^{-1}$ respectivamente) observadas na dose de $80 \mathrm{~kg} \mathrm{ha}^{-1}$ de N (Figura 5b,e). Não se observou resposta do rendimento de gráos às doses de adubaçáo nitrogenada, quando o trigo foi cultivado em sucessắo ao nabo forrageiro e à ervilhaca comum (Figura $5 \mathrm{c}$,d) devido, provavelmente, à alta disponibilidade de nitrogênio liberado dos resíduos culturais (Figura 4a); a ervilha forrageira, por exemplo, aos 42 dias após o manejo, contribuiu com $105 \mathrm{~kg} \mathrm{ha}^{-1}$ de nitrogênio (Figura 4a). Em sucessão à ervilha forrageira, a ocorrência de acamamento resultou em decréscimo no rendimento de grăos a partir da dose de $80 \mathrm{~kg} \mathrm{ha}^{-1}$ de N (Figura 5a), o que pode ser explicado pela maior disponibilidade hídrica na safra agrícola em questão (Figura 1). Neste contexto, Braz et al. (2006), avaliando o cultivo de trigo em sucessão a diferentes espécies de cobertura, também observaram que a resposta do trigo à adubação nitrogenada foi dependente das condiçóes meteorológicas e que a utilização de altas doses de nitrogênio favoreceu o acamamento.

Após a resteva do milho, observou-se resposta linear positiva do rendimento de grãos de trigo à aplicação de nitrogênio (Figura 5f); a ausência de acamamento em ambos os anos, mesmo na maior dose de adubação nitrogenada, deveu-se à alta relação $\mathrm{C} / \mathrm{N}$ do milho (Figura $2 \mathrm{~b}$ ), fato que, possivelmente, favoreceu a imobilização do nitrogênio, diminuindo a disponibilidade para a cultura do trigo. Em 2010, em todos os tratamentos, observou-se resposta linear positiva às doses de adubação nitrogena$\mathrm{da}$, atingindo as maiores produtividades na maior dose de adubação nitrogenada. $\mathrm{O}$ rendimento de grãos em sucessão à ervilha forrageira sem adubação nitrogenada foi equivalente ao alcançado em sucessão à palhada de milho 

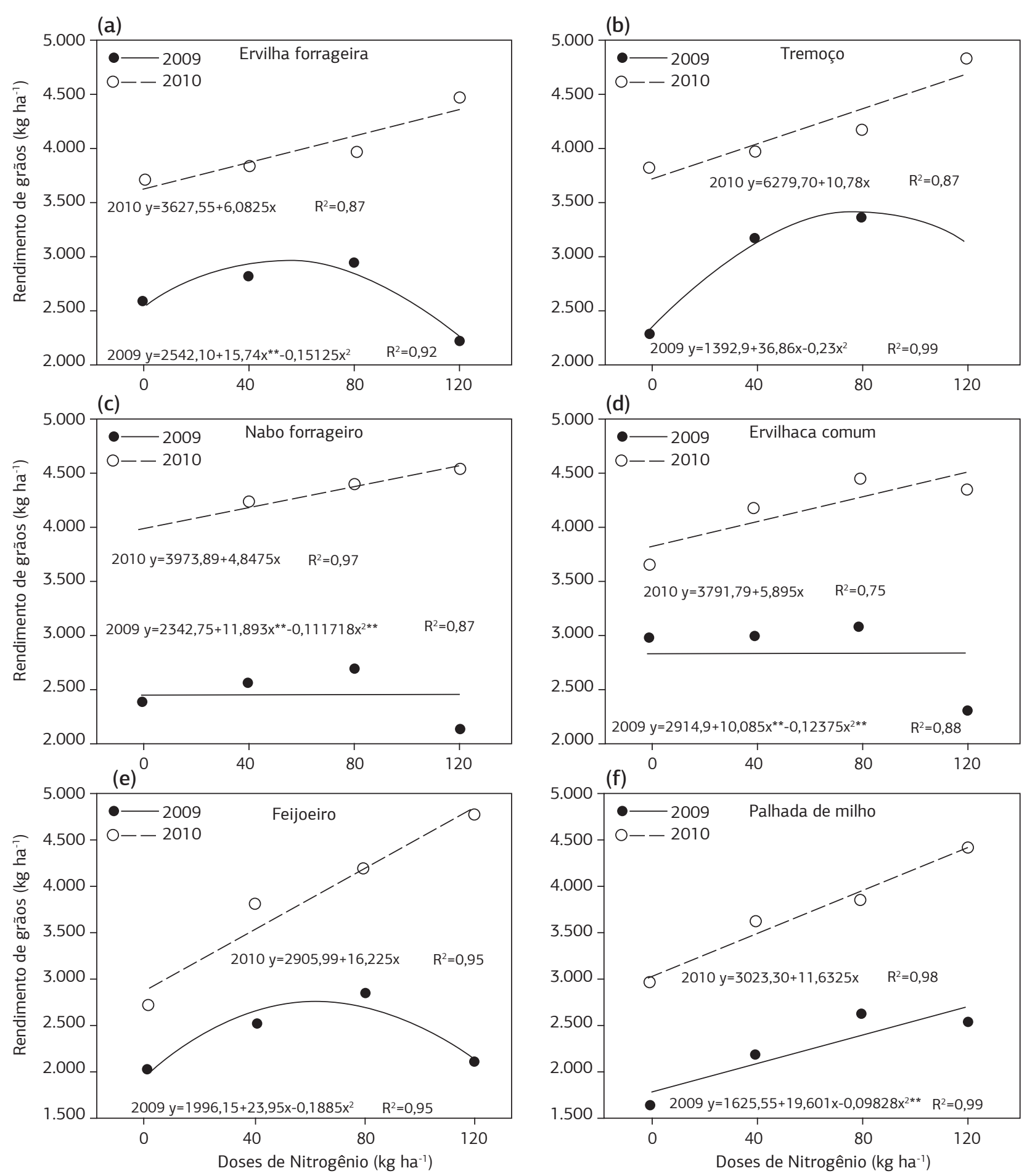

Figura 5. Ajuste das equaçôes de regressão para o rendimento de grãos de trigo cultivado em sucessão a cinco espécies outonais e resteva de milho, sob quatro doses de adubação nitrogenada (0, 40, 80 e $\left.120 \mathrm{~kg} \mathrm{ha}^{-1}\right)$ nas safras agrícolas de 2008/2009 e 2009/2010. **Parâmetro não significativo $(\mathrm{p} \geq 0.05)$ pelo teste $t$. Pato Branco (PR), 2010.

com 80 (2009) e 40 (2010) $\mathrm{kg} \mathrm{ha}^{-1}$ de N (Figura 5a,f). Tais resultados corroboram com Voss et al. (2004), que indicaram a necessidade de $80 \mathrm{~kg} \mathrm{ha}^{-1} \mathrm{de} \mathrm{N}$ em trigo após pousio, para obter rendimento equivalente após a sucessão com a ervilha forrageira, sem aplicação de nitrogênio.

Em 2009, o rendimento de gráos do trigo em sucessão à ervilhaca comum, sem adubação nitrogenada, foi superior ao observado nas maiores doses de adubação $\left(80\right.$ e $120 \mathrm{~kg} \mathrm{ha}^{-1}$ de N), em sucessão ao feijoeiro e à palhada de milho. Também em 2010, verificou-se que o rendimento de grãos em sucessão à ervilhaca comum (sem aplicação de nitrogênio) foi semelhante ao observado em sucessão à palhada de milho, com 40 $\mathrm{kg} \mathrm{ha}^{-1}$ de N. Ainda em 2009, o rendimento de grãos 
de trigo cultivados em sucessão à ervilha forrageira, ao nabo forrageiro e à ervilhaca comum, sem adubação nitrogenada, foi semelhante aos observados quando cultivados em sucessão à palhada de milho com 80 , 40 e $80 \mathrm{~kg} \mathrm{ha}^{-1}$ de $\mathrm{N}$ respectivamente (Figura 5a,c,e). Comparando-se o rendimento de gráos de trigo no pousio, sem nitrogênio, verifica-se que foram necessários 40 e $80 \mathrm{~kg} \mathrm{ha}^{-1}$ de $\mathrm{N}$, respectivamente, em 2009 e 2010, para se alcançar rendimento de grãos equivalente ao obtido após nabo forrageiro sem adubação nitrogenada (Figura 5c,e). Estas equivalências se justificam pela contribuição da ervilha forrageira, nabo forrageiro e ervilhaca comum que, aos 42 dias após o manejo (período em que coincidiu com o afilhamento do trigo), liberaram 105, 56 e $64 \mathrm{~kg} \mathrm{ha}^{-1}$ de N respectivamente e, aos cem dias após o manejo (fase de enchimento de grãos de trigo) contribuíram com 111,71 e $77 \mathrm{~kg} \mathrm{ha}^{-1}$ de N. Além disso, a ervilha forrageira e o nabo forrageiro tiveram melhor dinâmica de fornecimento deste nutriente, com sincronia entre o nutriente liberado e os estádios de maior demanda da cultura do trigo (Figura 4a).

Dessa forma, o cultivo de adubos verdes entre a colheita do milho e a semeadura do trigo, torna-se uma prática de manejo viável e sustentável, pois permite suprir e/ou complementar a adubação nitrogenada mineral, reduzindo os custos de produção e o impacto ambiental.

\section{CONCLUSÃO}

O uso de adubos verdes cultivados entre as culturas do milho e do trigo em substituição ao pousio, incorporam matéria seca ao sistema e reciclam nutrientes, proporcionando benefícios à cultura do trigo cultivada em sucessão. A ervilha forrageira e o nabo forrageiro destacam-se pela produção de matéria seca, acúmulo de nitrogênio, fósforo, potássio, bem como pela decomposição e liberação de nitrogênio para a cultura do trigo, em estádios fenológicos de maior demanda deste nutriente. A resposta do trigo à aplicaçấo de nitrogênio mineral é dependente da cultura antecessora e das condições meteorológicas.

\section{REFERÊNCIAS}

AGOSTINETTO, D.; FERREIRA, F.B.; STOCH, G.; FERNANDES, F.F.; PINTO, J.J.O. Adaptação de espécies utilizadas para cobertura de solo no sul do Rio Grande do Sul. Revista Brasileira de Agrociência, v.6, p.47-52, 2000.

AITA, C.; BASSO, C.J.; CERETTA, C.A.; GONÇALVES, C.N.; DA ROS, C.O. Plantas de cobertura de solo como fontes de nitrogênio ao milho. Revista Brasileira de Ciência do Solo, v.25, p.157-165, 2001.
AITA, C.; GIACOMINI, S.J. Decomposição e liberação de nitrogênio de resíduos culturais de plantas de cobertura de solo solteiras e consorciadas. Revista Brasileira de Ciência do Solo, v.27, p.601-612, 2003.

ALMEIDA, K.; CÂMARA, F.L.A. Produção de fitomassa e acúmulo de nitrogênio em espécies de adubos verdes de inverno. Revista Brasileira de Agroecologia, v.2, p.1224-1227, 2007.

ALVARENGA, R.G.; COSTA, L.M.; MOURA FILHO, W.; REGAZZI, A.J. Características de alguns adubos verdes de interesse para a conservação e recuperação de solos. Pesquisa Agropecuária Brasileira, v.30, p.175-185, 1995.

BRAZ, A.J.B.P.; SILVEIRA, P.M.; KLIEMANN, H.J.; ZIMMERMANN, F.J.P. Adubação nitrogenada em cobertura na cultura do trigo em sistema de plantio direto após diferentes culturas. Ciência e Agrotecnologia, v.30, p.193-198, 2006.

CAMPOS, H. Estatística experimental não-paramétrica. 4.ed. Piracicaba: ESALQ/FEALQ, 1983.349p.

CRUZ, C.D. Programa Genes: Biometria. Viçosa: Editora UFV, 2006. 382p.

GIACOMINI, S.J.; AITA, C.; HÜBNER, A.P.; LUNKES, A.; GUIDINI, E.; AMARAL, E.B. Liberação de fósforo e potássio durante a decomposição de resíduos culturais em plantio direto. Pesquisa Agropecuária Brasileira, v.38, p.1097-1104, 2003 a.

GIACOMINI, S.J.; AITA, C.; VENDRUSCOLO, E.R.O.; CUBILlA, M.; NICOLOSO, R.S.; FRIES, M.R. Matéria Seca, relação $\mathrm{C} / \mathrm{N}$ e acúmulo de nitrogênio, fósforo e potássio em misturas de plantas de cobertura de solo. Revista Brasileira de Ciência do Solo, v.27, p.325-334, 2003b.

HEINRICHS, R.; AITA, C.; AMADO, T.J.C.; FANCELLI, A.L. Cultivo consorciado de aveia e ervilhaca: relaçáo $\mathrm{C} / \mathrm{N}$ da fitomassa e produtividade do milho em sucessão. Revista Brasileira de Ciência do Solo, v.25, p.331-340, 2001.

KOCHHANN, R.A.; SANTOS, H.P.; VOSS, M.; DENARDIN, J.E. Rendimento de grãos de trigo cultivado em seqüência ao adubo verde nabo forrageiro. Passo Fundo: Embrapa Trigo, 2003. 12p. (Embrapa Trigo. Comunicado Técnico Online, 116). Disponível em: <http://www.infoteca.cnptia.embrapa.br/handle/ doc/852298>. Acesso em: 10/4/2012.

LARA-CABEZAS, W.A.R.; TRIVELIN, P.C.O.; KONDÖRFER, G.H.; PEREIRA, S. Balanço da adubação nitrogenada sólida e fluida de cobertura na cultura de milho, em sistema de plantio direto no Triângulo Mineiro (MG). Revista Brasileira de Ciência do Solo, v.24, p.363-376, 2000.

LIMA, J.D.; ALDRIGHI, M.; SAKAI, R.K.; SOLIMAN, E.P.; MORAES, W.S. Comportamento do nabo forrageiro (Raphanus sativus L.) e da nabiça (Raphanus raphanistrum L.) como adubo verde. Pesquisa Agropecuária Tropical, v.37, p.60-63, 2007.

MEURER, E.J.; INDA JUNIOR, A.V. Potássio e adubos potássicos. In: BISSANI, C.A.; GIANELLO, C.; TEDESCO, M.J.; CAMARCO, F.A.O. Fertilidade dos solos e manejo da adubação de culturas. Porto Alegre: Gênesis, 2004. p.139-152. 
NUNES, A.S.; SOUZA, L.C.F.; MERCANTE, F.M. Adubos verdes e adubação mineral nitrogenada em cobertura na cultura do trigo em plantio direto. Bragantia, v.70, p.432-438, 2011.

PAUL, E.A.; CLARK, F.E. Soil microbiology and biochemistry. California: Academic Press, 1996. 340p.

STELL, R.G.D.; TORRIE, J.H.; DICKEY, D.A. Principles and procedures of statistics: a biometrical approach. 3.ed. New York: McGraw-Hill, 1997. 666p.

STUTE, J.K.; POSNER, J.L. Synchrony between legume nitrogen release and corn demand in the upper Midwest. Agronomy Journal, v.87, p.1063-1069, 1995.

TEDESCO, M.J.; GIANELLO, C.; BISSANI, C.A.; BOHNEN, H.; VOLKWEISS, S.J. Análise de solo, plantas e outros materiais. 2.ed. Porto Alegre: Universidade Federal de Rio Grande do Sul, 1995. 174p.

VOSS, M.; TOMM, G.O.; SANTOS, H.P.; WIETHÖLTER, S. Ervilha forrageira como adubo verde para o trigo: resultados preliminares. Passo Fundo: Embrapa Trigo, 2004. 5p. (Embrapa Trigo. Comunicado Técnico Online, 139)

WENDLING, A.; ELTZ, F.L.F.; CUBILLA, M.M.; AMADO, T.J.C.; MIELNICZUK, J.; LOVATO, T. Recomendação de adubação nitrogenada para trigo em sucessão ao milho e soja sob sistema plantio direto no Paraguai. Revista Brasileira de Ciência do Solo, v.31, p.985-994, 2007.

WIEDER, R.K.; LANG, G.E. A critique of the analytical methods used in examining decomposition data obtained from litter bags. Ecology, v.63, p.1636-1642, 1982. 